\title{
Reflexiones sobre el actual ejercicio profesional del cirujano
}

\section{Some reflextions about surgeon’s practice}

La emergente tecnología y el desarrollo vertiginoso de las comunicaciones han generado un fuerte impacto en el trabajo quirúrgico. A la generación a la cual pertenezco la ha correspondido vivir el cambio que ha significado la tradicional cirugía por amplias incisiones a la pequeña invasión. Hemos aprendido a operar mirando en dos dimensiones, con instrumentos nuevos y hemos reemplazado una variedad de formas de usar suturas manuales por maquinas que aplican corchetes. El avance en el manejo del paciente crítico en las unidades especiales, la aparición de nuevos fármacos controlando de mejor forma el dolor y las infecciones, el progreso de la anestesia en monitoreo y seguridad, han permitido al cirujano alcanzar mejores resultados y poder aventurarse con más seguridad en complejos procedimientos. Por ejemplo, notables han sido los avances en los trasplantes de órganos y las actuales opciones de sobrevida de los trasplantados.

La industria estimula la innovación y el cambio, crea nuevas necesidades y el cirujano a veces deslumbrado por lo nuevo, se ve enfrentado a incentivos que le son difíciles de controlar y puede fácilmente involucrarse en situaciones que merecen un análisis en la perspectiva de la ética médica. Las relaciones entre la industria de la salud y los médicos son un gran tema para reflexionar.

La ciencia de la computación hace maravillas con la tecnología aplicada a la salud con mejores imágenes que facilitan el diagnóstico y el conocimiento de la anatomía, robótica que facilita los delicados movimientos quirúrgicos y nuevos instrumentos que permiten más tratamientos, ahora a través de orificios naturales. Con ello la cirugía por pequeñas incisiones ha extendido su campo en todas las áreas, y el cirujano se adapta a una diferente forma de hacer su procedimiento.

También el mundo global se comunica de otra forma. Antes consultábamos gruesos volúmenes del INDEX Medicus buscando bibliografías, hoy todo está al alcance de un clic en la web. La inmediatez y la facilidad de informarse han generado cambios en los pacientes y también nos ha hecho cambiar a nosotros los cirujanos. Los pacientes llegan informados y con opiniones extraídas de la web, no siempre correctas. Ello ha significado un gran cambio en la relación médico-paciente-familia. Vemos que en la atención ambulatoria del cirujano especialista, el paciente llega con un alto de sobres con imágenes y una variedad de papeles con exámenes e informes, y en un plazo breve solicita opiniones e interpretaciones. El cirujano no debe modificar su forma de hacer buena medicina, ya que todos esos exámenes sólo deben ser analizados después de haber completado una buena anamnesis y el correspondiente examen físico. Frecuente es el paciente que ingresa a la visita quirúrgica blandiendo una ecografía de partes blandas y diciendo que le encontraron una hernia inguinal de $9 \mathrm{~mm}$. Con frecuencia el análisis clínico nos convence que el problema que lo trae es diferente. Cuidado con caer en la tentación de operar ecografías o escáneres, recordar que al frente tenemos una persona, un paciente.

El médico ha perdido su aura sacerdotal, ese rol del brujo de la tribu. La relaciones interpersonales son más abstractas, estamos confiando más en los sistemas u organizaciones que en las personas individualmente. Existe mayor autonomía personal, y las personas se sienten más empoderadas de derechos que de obligaciones. El narcisismo contemporáneo lleva a más preocupación por el cuerpo visible y hay una continua búsqueda para evitar el dolor, no sólo de tipo físico. El uso de fármacos que sustentan el ánimo y mejoran la vitalidad es masivo. El consumo se masifica y la salud es parte de ese consumo.

El médico ya no es el único que posee la información, cualquiera que busca también la encuentra en la web. Nuestros errores o imprecisiones son fácilmente cuestionables y la palabra negligencia se usa livianamente. Las demandas médico legales ya no son una novedad en nuestro medio. El médico suele 
ser visto como un prestador de servicio y la relación médico-paciente se va transformando en médico y cliente, no sólo en el mundo de la salud privada.

La forma de enfrentar este nuevo escenario y esta particular nueva relación médico-paciente-familia es con profesionalismo. Esta palabra profesionalismo implica no sólo conocimientos, habilidades y destrezas, sino que también acogimiento, humanidad, dedicación al paciente, transparentar los problemas y enfrentar las dificultades y complicaciones con honestidad y entrega.

Con frecuencia nos solicitan recomendar un buen médico para un determinado problema. Cuando yo pienso en un buen especialista no lo hago sólo por sus habilidades quirúrgicas, sino por además de conocer muy bien su oficio, estar disponible, tener inteligencia emocional, ser dedicado a sus pacientes y honrado en su juicio. Eso a mi entender es actuar en cirugía con profesionalismo.

Los actuales requerimientos de acreditación de especialistas y recertificación obligarán a los cirujanos documentar sus competencias y actividades, para lo cual los cursos y congresos tendrán una valoración especial.

Hemos estado preocupados por la calidad y consistencia de la educación de postgrado en Chile frente a los nuevos requerimientos y desafios que hoy se plantean. La duración del postgrado de 3 años en cirugía general, escasa oportunidad de financiamiento del becado que no tiene beca sino que muchas veces debe autofinanciarse para acceder a la capacitación a costa de horas que debiera dedicar a su formación, las limitaciones de los campos clínicos, son aspectos que requieren de nuestra preocupación. La Sociedad publicó en nuestra Revista Chilena de Cirugía en enero 2008 las definiciones y contenidos de un programa de Cirugía General, inspirado en varios modelas extranjeros, en particular con el formato español. Queda aún mucho por hacer en esta área y nuestros especialistas deben aportar a la estructuración de conceptos del postgrado en sus sectores.

La calidad en la atención es otro gran tema en los años venideros. Mediante la nueva legislación y las atribuciones de la Autoridad Sanitaria se hará efectiva durante el año 2009 la acreditación de hospitales y clínicas. El trabajo en el área quirúrgica es altamente demandante para cumplir con los estándares de calidad planteados, no en conceptos, ya que son fáciles de acoger, sino en cambios culturales y formas de trabajar que resultan más difíciles de implementar. Consentimiento informado, visita preoperatoria, aplicación del procedimiento correcto en el sitio correcto y paciente correcto, registro quirúrgico, monitoreo de eventos inesperados, manejo del dolor, protocolos de trabajo, reuniones de morbimortalidad y transparentar resultados e indicadores de calidad, entre otros, son tareas ineludibles que requieren de la participación activa de toda la comunidad quirúrgica, que se proyectará, sin lugar a dudas en una mejor atención a nuestros pacientes.

Si el mundo está cambiando, la sociedad cambia y nos hace cambiar. Los incentivos económicos y valóricos tienden a hacer cambiar al cirujano. Sin pretender quedarse en el pasado o ser una mutación social, debemos luchar por mantener nuestros valores profesionales y los principios quirúrgicos que hemos heredados de nuestros maestros y proyectarlos en nuestros alumnos.

Con frecuencia se nos pregunta que valor tiene pertenecer a nuestra Sociedad de Cirujanos. Es indudable que el rol de las Sociedades Científicas debe evolucionar junto con los cambios sociales. Los cirujanos deben contar con una organización que vele por sus intereses profesionales y que fomente la atención quirúrgica de calidad para el país, tanto en el sector estatal como en el privado. Para ello necesitamos una Sociedad de Cirujanos fuerte, participativa, que represente adecuadamente los distintos sectores de nuestra cirugía, tenga una opinión sobre los temas contingentes y capacidad de influir en el desarrollo de la salud nacional.

Dr. Juan Hepp K.

Profesor de Cirugía

Facultad de Medicina Clínica Alemana-Universidad del Desarrollo Past Presidente Sociedad de Cirujanos de Chile. 